\title{
Systemic resistance induction in 'Ortanique' tangor
}

\author{
Marines Batalha Moreno Kirinus ${ }^{1}$, Pricila Santos da Silva ${ }^{2}$, Caroline Farias Barreto ${ }^{3}$, \\ Roberto Pedroso de Oliveira ${ }^{4}$, Marcelo Barbosa Malgarim ${ }^{5}$
}

\begin{abstract}
This study aimed to evaluate the quality of 'Ortanique' tangor, in the post-harvest and refrigerated storage after application of pre-harvest resistance inducers, in the 2015 and 2016 crops. The experimental design in the field was in completely randomized blocks, in a single factorial scheme. The treatment factor was composed of the following resistance inducers [without inducer, selenium (Se), silicon (Si), acibenzolar-s-methyl (ASM), methyl jasmonate (MeJa), thiamethoxam (TMT) and imidacloprid (IMI)]. In the laboratory, the design used was the same as that established in the field, but in a two-factorial scheme, where factor A was composed of the same inducers and factor $\mathrm{B}$, for the storage period [zero (fruits that were not submitted to storage) and 30 days (Cold chamber $5 \pm 1^{\circ} \mathrm{C}$, relative humidity 85 to $95 \%$ )], with simulation of the commercialization time $\left(7\right.$ days at $\left.20 \pm 1^{\circ} \mathrm{C}\right)$. The following analysis were performed: coloration $(\mathrm{L} *, \mathrm{a} *, \mathrm{~b} *$ and hue), fresh mass loss, rot index, soluble solids (SS), $\mathrm{pH}$, titratable acidity (TA), SS/TA ratio, ascorbic acid, phenolic compounds and antioxidant capacity. The application of resistance inducers reduces the percentage of fresh mass loss and fruit rot after 30 days of refrigerated storage. Inducers keep phenolic compounds and antioxidant capacity, both in pulp and fruit peel, over the storage period. The inducers Si, MeJa and IMI provide phytochemicals improvement, when compared to the control.
\end{abstract}

Index Terms: Citrus sinensis x Citrus reticulate, elicitors, refrigerated storage, rot.

\section{Indução de resistência sistêmica em tangor 'Ortanique'}

Corresponding author: marinesfaem@gmail.com

Received: August 31, 2018 Accepted: January 10, 2019

Copyright: All the contents of this journal, except where otherwise noted, is licensed under a Creative Commons Attribution License.

\section{(cc) $\mathbf{E Y}$}

Resumo - Este estudo objetivou avaliar a qualidade do tangor 'Ortanique' na pós-colheita e no armazenamento refrigerado após aplicação de indutores de resistência na pré-colheita, nas safras de 2015 e 2016. O delineamento experimental a campo foi em blocos completos casualizados, em esquema unifatorial. $\mathrm{O}$ fator de tratamento foi composto pelos indutores de resistência [sem indutor (testemunha), selênio (Se), silício ( $\mathrm{Si}$ ), acibenzolar-s-metil (ASM), metil jasmonato (MeJa), tiametoxam (TMT) e imidacloprido (IMI)]. No laboratório, o delineamento utilizado foi o mesmo estabelecido a campo, porém em esquema bifatorial, em que o fator A foi composto pelos mesmos indutores, e o fator B, pelo período de armazenamento [zero (frutos que não foram submetidos ao armazenamento) e 30 dias (câmara fria $5 \pm 1{ }^{\circ} \mathrm{C}$, umidade relativa de $90 \pm 5 \%$ )], com simulação do tempo de comercialização $\left(7\right.$ dias a $\left.20 \pm 1^{\circ} \mathrm{C}\right)$. As análises realizadas foram coloração ( $L^{*}, a^{*}, b^{*}$ e hue), perda de massa fresca, índice de podridões, sólidos solúveis (SS), pH, acidez titulável (AT), razão SS/AT, ácido ascórbico, compostos fenólicos e capacidade antioxidante. A aplicação dos indutores de resistência reduz o percentual de perda de massa fresca e podridões nos frutos após 30 dias de armazenamento refrigerado. Os indutores mantêm os compostos fenólicos e a capacidade antioxidante, tanto na polpa quanto na casca dos frutos, ao longo do período de armazenamento. Os indutores $\mathrm{Si}$, MeJa e IMI proporcionam aumento dos fitoquímicos quando comparados à testemunha.

Termos para Indexação: Citrus sinensis x Citrus reticulata, elicitores, armazenamento refrigerado, podridão.

\footnotetext{
${ }^{1}$ Dra. Professora colaboradora Eng. Agrônoma/Universidade Federal de Pelotas, Av. Eliseu Maciel, s/n - 96050-500, Capão do Leão/RS, Brasil, Email: marinesfaem@gmail.com ${ }^{\text {(ORCID 0000-0001-9375-5215) }}$

${ }^{2}$ Msc. Eng. Agrônoma, doutoranda de Pós-Graduação em Produção Vegetal/Universidade do Estado de Santa Catarina, Lages/SC, Brasil, Email: pricilassilva@hotmail.com ${ }^{\text {(ORCID 0000-0002-4102-1292) }}$

${ }^{3}$ Msc. Eng. Agrônoma, doutoranda de Pós-Graduação em Agronomia/Universidade Federal de Pelotas, Capão do Leão/RS, Brasil, Email: carol_fariasb@hotmail.com ${ }^{\text {(ORCID 0000-0002-5568-5305) }}$

${ }^{4}$ Dr. Pesquisador Eng. Agrônomo, Embrapa Clima Temperado, Pelotas/RS, Brasil, Email: roberto.pedroso@embrapa.br ${ }^{(0 R C I D}$ 0000-0002-1377-0990) ${ }^{5}$ Dr. Professor Adjunto Eng. Agrônomo, Universidade Federal de Pelotas, Capão do Leão/RS, Brasil, Email: malgarim@ufpel.edu.br ${ }^{(0 R C I D}$ 0000-0002-3584-5228)
} 


\section{Introduction}

The Brazilian citriculture is dedicated mainly to produce oranges to be used as raw materials of the juice industry. The state of São Paulo accounts for $76.3 \%$ of the national citrus production, followed by the states of Bahia, Sergipe, Rio Grande do Sul and Paraná. Of 19 million tons harvested per crop, approximately 1.5 million tons correspond to the production of 'Tahiti' acid lime [Citrus latifolia Tanaka] and tangerines, such as 'Ponkan' [Citrus Reticulata Blanco] and tangor 'Murcott' [Citrus sinensis L. Osbeck x Citrus reculata Blanco] (FAO, 2016).

With the expansion of acreage and densification of orchards, there was increase of damage caused by different pathogens, the major causes of reduced productivity (ALBRECHT et al., 2012; BOCK et al., 2011). As there are not always tolerant genotypes available, the control of these pathogens is usually accomplished with chemical pesticides. However, the demand for producing healthier food is gaining more and more importance, requiring the search for alternative approaches to pesticides for pathogen control. In this context, the use of systemic acquired resistance (SAR) is a defense mechanism induced by biotic or abiotic agents, which gives long-lasting protection against a broad spectrum of microorganisms, causing a wide variety of metabolic and physiological responses (AGHDAM et al., 2016), related to direct and indirect defense in the secondary metabolism (ROBERT-SEILANIANTZ et al., 2011).

Among the substances that promote resistance induction, highlighting their ability to activate fruit defenses, such as in citrus, are selenium, silicon, acibenzolar-s-methyl, methyl jasmonate and neocotinoids. Selenium regulates the expression of genes involved in the ethylene biosynthesis, which can slow down ripening and improve antioxidant defense system (ZHU et al., 2017), thereby increasing the potential of plants to fight stressful conditions (HANDA et al., 2016). Silicon is a beneficial nutrient, which operates in the metabolic system of the plants, inducing resistance (IMTIAZ et al., 2016), increasing cell wall fragments (ZHICHAO et al., 2016) and enzymatic activity of plant tissues (CONCEIÇÃO et al., 2014). Acibenzolar-s-methyl is able to activate proteins of pathogenesis, generating plant defense, as reported in apple (QUAGLIA et al., 2011) and citrus (NETO et al., 2015). Methyl jasmonate is important in the process of molecular signaling, raising the activation and induction of defense genes expression in citrus (ALBRECHT; BOWMAN, 2012; FAN et al., 2011). Substances such as the neocotinoids have property to induce systemic resistance in citrus plants (GRAHAM; MYRES, 2011).

Due to the great functionality of resistance inducers in plants, specific studies must be carried out in pre-harvest, improving their applications and expected results, consequently, providing production security. This study aimed to evaluate the quality of 'Ortanique' tangor [Citrus reticulata Blanco x Citrus sinensis (L.) Osbeck] fruit in post-harvest and under refrigerated storage after the application of resistance inducers in pre-harvest in the 2015 and 2016 crops.

\section{Material and Methods}

The experiment for the application of resistance inducers was carried out in the field, in the 2015 and 2016 crops, in a commercial orchard $\left(31^{\circ} 40^{\prime} 47^{\prime \prime} \mathrm{S}\right.$ and $52^{\circ} 26^{\prime} 24^{\prime}$ 'O, with $60 \mathrm{~m}$ above sea level), located in Monte Bonito, $9^{\text {th }}$ district of the municipality of Pelotas, Rio Grande do Sul (RS), Brazil. The soil in the region is moderately deep, with medium texture in the A horizon and clayey in the B horizon, classified as Yellow-Red Argisoil (SANTOS et al., 2006). The climate of the region is $\mathrm{Cfa}$, i.e., temperate or humid subtropical with hot summers (KÖPPEN; GEIGER, 1928) with average annual rainfall of $1590 \mathrm{~mm}$, annual average temperature of $18.4^{\circ} \mathrm{C}$ and relative humidity annual average $78.8 \%$ (INMET, 2016).

The 'Ortanique' tangor [Citrus reticulata Blanco $\mathrm{x}$ Citrus sinensis (L.) Osbeck] plants with 6 years grafted onto 'Rangpur' lime [Citrus limonia Osbeck] with $5-\mathrm{m}$ spacing between rows and $4 \mathrm{~m}$ between plants. The experimental field was handled in accordance with the requirements of integrated citrus production (AZEVEDO et al., 2010). The orchard was applied with Nativo ${ }^{\circledR}$ fungicide (Trifloxystrobin 100 g.L ${ }^{-1}$ and Tebuconazole 200g. $\mathrm{L}^{-1}$ ), 3 applications spaced 30 days. The first application was in the phenological stage of newly formed fruits and the application of the Bordeaux mixture (copper sulfate and lime) with 6 applications spaced 45 days, from flowering to 60 days before harvest.

The experimental design the field for the application of resistance inducers was in complete randomized blocks, with five repetitions, three plants per plot, by evaluating the central plant, in unifactorial scheme. The treatment was composed of resistance inducers [no inducer (control, water), selenium (Se, 10 mg. $\mathrm{L}^{-1}$ ), silicon ( $\mathrm{Si}, 400 \mathrm{mg} . \mathrm{L}^{-1}$ ), acibenzolar-smethyl (ASM, $100 \mathrm{mg} \cdot \mathrm{L}^{-1}$ ), methyl jasmonate (MeJa, $10 \mathrm{mg} . \mathrm{L}^{-1}$ ), Thiamethoxam (TMT, $2000 \mathrm{mg} . \mathrm{L}^{-1}$ ) and Imidacloprid (IMI, 714mg.L-1 $\mathrm{L}^{-1}$ )]. These concentrations were established through preliminary tests in 'Murcott' tangor [Citrus sinensis L. Osbeck x Citrus reculata Blanco] and 'Oktisu' tangerine [Citrus unshiu Marc.], in an experimental area of Embrapa, and based on the literature.

The application of resistance inducers occurred at a 15-day interval, totaling three applications in the 
orchard, at 45, 30 and 15 days before harvest, with total dosage in each application. The products $\mathrm{Si}, \mathrm{ASM}$ and MeJa were applied with knapsack $\left(\right.$ Guarani $\left.^{\circledR}\right)$, with flat fan nozzle and fine droplet size $(101-200 \mu)$, throughout the plant, avoiding run-off. For Se, TMT and IMI inducers, each product was prepared and then applied in the soil around the plant canopy. The total volume of each treatment applied was $1 \mathrm{~L}$.plant- ${ }^{1}$, in all treatments, $0.1 \%$ of nonionic Silwet adhesive L- $77^{\circledR}$ adhesive spreader was added. The fruits were collected at ideal maturation for marketing, randomly in four quarters of the plant canopy. They were placed in plastic boxes cleaned and disinfected, transported to the Physiology Laboratory and Post-Harvest Technology of Fruit, Department of Crop Science at the Universidade Federal de Pelotas (UFPel), where they were submitted to pre-screening for standardization, by removing damaged fruits, and precooling $\left(15 \pm 2^{\circ} \mathrm{C}\right)$ for 24 hours.

In the laboratory the design used was the same as established in the field, but in a two-factorial scheme, where factor A was composed of the same resistance inducers described previously and factor $\mathrm{B}$, a storage period (zero and 30 days). The zero time corresponded to fruits that were not subjected to storage and at 30 days of storage in a cold chamber at $5 \pm 1{ }^{\circ} \mathrm{C}$ under $85-95 \%$ of relative humidity. After removing from the chamber, the fruits were subjected to simulation of commercialization time, 7 days at $20 \pm 1^{\circ} \mathrm{C}$. For each treatment, three replicates were used with 20 fruits each and the same quantity was allocated to refrigerated storage, totaling 840 fruits.

The analyses made were coloring $\left(\mathrm{L}^{*}, \mathrm{a}^{*}, \mathrm{~b}^{*}\right.$ and hue), fresh mass loss, rot index, soluble solids (SS), $\mathrm{pH}$, titratable acidity (TA), SS/TA ratio, ascorbic acid, phenolic compounds and antioxidant capacity. The pulp color was measured with Minolta colorimeter CR-300, with reading system CIE L* $\mathrm{a}^{*} \mathrm{~b}^{*}$, and the chromatic tone, represented by the hue angle $\left(h^{\circ}\right)$ through the arctangent formula $b^{*} / a^{*}$. The result of this equation, expressed in radians, was converted into degrees (MINOLTA, 1994).

The fresh mass loss of fruits was obtained by the difference between the initial and final mass of the cold storage period and the values expressed in percentage (\%). The rot index was established by the percentage of fruit attacked by pathogens through visual inspection, where fruits with lesion greater than or equal to $5 \mathrm{~mm}$ were considered rot. Both evaluations were conducted after 30 days of refrigerated storage.

The soluble solids (SS) were quantified with digital Refractometer (Atago ${ }^{\circledR}$ ) model PAL-1 and the results were expressed in ${ }^{\circ}$ Brix. The hydrogen potential $(\mathrm{pH})$ was measured through a digital $\mathrm{pH}$ meter (Digimed $\left.{ }^{\circledR}\right)$. For titratable acidity (TA), $10 \mathrm{ml}$ of fruit juice was added to $90 \mathrm{~mL}$ of distilled water. The sample titration was made with the aid of digital burette
(Brand $\left.{ }^{\circledR}\right)$, containing sodium hydroxide solution (0.1 N) until reaching $\mathrm{pH} 8.1$, the values were expressed in percentage of citric acid. The SS/TA ratio of tangor was expressed by the relationship between the soluble solids and titratable acidity (INSTITUTO ADOLFO LUTZ, 2008). The ascorbic acid content was quantified through the official AOAC method (1997) by oxidative titration with 2.6-DiclorofenolIndofenol (DCFI), with the titration point detected by the appearance of the pink coloration, the result was expressed in mg of ascorbic acid per 100 $\mathrm{g}^{-1}$ of sample (JACOBS, 1958; LEME; MALAVOLTA, 1950).

To analyze the phytochemicals of 'Ortanique' tangor the exocarp or epicarp (peel) of the endocarp (pulp) were separated and evaluated separately. The total phenolic compounds were quantified using the Folin-Ciocalteau reagent according to the method described by Swain and Hillis (1959), expressed in $\mathrm{mg}$ of chlorogenic acid equivalent (CAE) per $100 \mathrm{~g}^{-1}$ of tangor. The antioxidant capacity was determined by spectrophotometry, according to the method adapted from Brand-Williams et al. (1995), and the results expressed as $\mu \mathrm{g}$ of Trolox equivalent antioxidant capacity (TEAC) $\mathrm{g}^{-1}$ of tangor.

The 2015 and 2016 crops were used as repetition. The data were analyzed for normality by the ShapiroWilk test and for homoscedasticity by the Hartley test. Subsequently, the data were submitted to analysis of variance $(p \leq 0.05)$. In case of significance, the effect of resistance inducers was examined by the Tukey test $(p \leq 0.05)$ and the storage period by the $t$ test $(p \leq 0.05)$. To compare the inducers with the control, the Dunnett test $(p \leq 0.05)$ was used. The presence of correlations between the dependent variables of the study was analyzed through the Pearson correlation coefficient ( $\mathrm{r})(p<0.05)$.

\section{Results and Discussion}

The variables color ( $\mathrm{L}^{*}$ and $\left.\mathrm{a}^{*}\right)$, titratable acidity, soluble solids and ascorbic acid showed interaction between the treatment factors tested (Table 1). When evaluating the coloring through luminosity $\left(\mathrm{L}^{*}\right)$, there was no difference between the inducers in both storage periods. However, after 30 days of refrigerated storage, the Selenium, ASM and TMT inducers kept the $\mathrm{L}^{*}$ values of the fruits.

Regarding the intensity of $\mathrm{a}^{*}$, there was no difference between the inducers; however, treatments with Si, ASM, MeJa, TMT and IMI provided increased intensity of reddish color throughout the storage period. For $\mathrm{L}^{*}$ and $\mathrm{a}^{*}$, the application of inducers did not differ when compared to control (Table 1). Coloring is a parameter used by citrus consumers, who prefer fresh and semi-ripened fruit (PACHECO et al., 2014). In this 
work, acceptable indices of coloring were kept, strong color and bright are preferred, although color, in most cases, does not contribute to an increase of nutritional value (CHITARRA; CHITARRA, 2005).

Regarding fruit acidity, the inducers differed from one another after 30 days of storage, and IMI, Se and TMT showed higher percentage of citric acid. When comparing the storage period, time zero differed from 30 days for the ASM, MeJa and IMI inducers. Only the neocotinoid IMI (1.85\% citric acid) differed from control. The soluble solids content of 'Ortanique' tangor did not present significant difference between the inducers at day zero. At 30 days of storage, the Selenium inducer characterized the highest soluble solids content, differing only from ASM. There was an increase along the storage period only for IMI. No differences were observed in relation to the control. The solids indicate the amount of sugar dissolved in juice or pulp of tangor fruits and tend to increase with the advancement of maturation (CHITARRA; CHITARRA, 2005). Fruits of 'URSBRS Hada' tangor of double purpose cultivated in Butiá - RS presented 12.2 and $12.1^{\circ}$ Brix and acidity of 1.59 to $1.65 \%$ of citric acid (GONZATTO et al., 2015), corroborating with the results found in this work.

ASM showed the lowest content of ascorbic acid between the inducers analyzed in both periods. During the cold storage period, the ascorbic acid reduced the presence of Se inducer. IMI showed higher results at both zero and 30 days of storage and Se only in the fruits that were not submitted to storage, when compared to control. Studies on 'Murcott' tangor fruit after 60 days of storage at $4 \pm 0.2^{\circ} \mathrm{C}$ and 7 days of shelf life at $20^{\circ} \mathrm{C}$ showed levels of fresh mass loss between 3 and $6 \%$, while keeping the physical and chemical qualities, such as ascorbic acid, soluble solids and titratable acidity (PINTO et al., 2015). This percentage of fresh mass loss is consistent with the data found in this study (Table 4).

For the conservation of 'Newhall' oranges, antimicrobial coatings were also studied as a way to reduce the use of agrochemicals, and it was observed that the clove extract reduced deterioration of fruits in cold storage at $7^{\circ} \mathrm{C}$, mainly for the physical-chemical characteristics, such as soluble solids, titratable acidity and ascorbic acid (ZENG et al., 2012).

The color expressed by $b^{*}$ and hue angle, besides the $\mathrm{pH}$ and SS/TA ratio, showed significance only for the main effect of the storage period (Table 3 ). For $b^{*}$ coloring, all fruits showed the intensity of yellow with positive values. Similarly, for hue in which the coloring of the fruit epidermis was characterized as yellow; however, both showed reduction throughout the storage period. The $\mathrm{pH}$ and SS/TA ratio of fruits increased with cold storage. Different results were found in 'Ortanique' tangor fruits subject to application of carnauba wax in post-harvest, where neither coating nor storage period influenced soluble solids, titratable acidity, $\mathrm{pH}$ and $\mathrm{SS}$ / TA ratio (MACHADO et al., 2012).

The reduction in the percentage of mass loss and rot index was significant with the application of inducers evaluated after 30 days of storage (Table 4). The MeJa inducer had greater fresh fruit mass loss, being different from other inductors and similar to control. Fresh mass loss is determined by the evaporation and respiration rate of tangor fruits, which must be kept to the minimum necessary to ensure fruit quality (CHITARRA; CHITARRA, 2005).

The percentage of rot index of the fruit showed that that inducers applied reduced rota long the storage period of 30 days, in relation to the control; however, they did not differ between each other, possibly by the short storage period of the fruit. Due to the advancement in the ripening degree, a greater susceptibility of tangor fruits to the development of pathogens occurred. Studies conducted by Wang and Liu (2012) in citrus fruits with the application of salicylic acid inducer showed various physiological and molecular events, which conferred resistance, reducing the incidence of rot and bacterial diseases.

For the total phenolics in pulp of 'Ortanique' fruit, the ASM inducer at initial time presented the lowest content of phenols; nevertheless, it was the only inducer showed no decrease throughout the storage period. The IMI inducers at zero and 30 days, and Se, Si and MeJa only at 30 days of refrigerated storage differed from control (Table 2). According to Siboza et al. (2014), MeJa combined with ASM kept the membrane integrity of lime fruits, becoming effective in tolerance to cold storage, in addition to increasing the phenolic compounds.

When these compounds were evaluated in peel, there was no difference between the inducers both at zero and at 30 days of cold storage. However, throughout storage, all inducers kept the levels of total phenolic compounds, with the exception of IMI. The Si and IMI inducers were superior to the control in both evaluations. For antioxidant capacity in fruit pulp, no difference between the inducers was observed both at the beginning and at end of storage, and all inducers kept the antioxidant capacity throughout the storage period. However, when compared with the control at day zero, all inducers, except for ASM, showed superior results. At 30 days of storage, however, only Si, MeJa and IMI were higher than control. The systemic neonicotinoid insecticides, IMI and TMT, reduced the incidence of disease in grapefruit and young orange (GRAHAM; MYERS, 2013).

Evaluation of the antioxidant capacity of fruit peel of 'Ortanique' tangor showed no difference between the inducers in the two periods evaluated. Throughout storage, the antioxidant capacity reduced, with the exception of inducer MeJa, which kept high levels and 
was the only inducer that differed from control in both storage periods thus inducing structural and/or metabolic responses associated with resistance expression. Moulehi et al. (2012) conducted an experiment and found that the antioxidant capacity of tangerine (Citrus reticulata) and bitter orange (Citrus auratium) varied during the ripening period, and the antioxidant capacity in orange was greater than in tangerine. In navel oranges [Citrus sinensis (L). Osbeck], the treatment with the inducer Oligochitosan spray in pre-harvest also proved to be a potential alternative to replace conventional control methods by preventing disease in post-harvest due to increase of the concentration of enzymes related to defense mechanisms (DENG et al., 2015).

When the fruit phenolic compounds were correlated with their total antioxidant capacity, the selenium ( $r=$ $0.518)$, silicon $(r=0.755)$, MeJa $(r=0.883)$ and TMT $(r=0.802)$ inducers characterized positive association between these variables, demonstrating that the capacity antioxidant of 'Ortanique' fruit is attributed to phenolic compounds, unlike the control, which showed no correlation. However, between the antioxidant capacity in peel and fruit phenols, the silicon inducers $(r=0.631)$ and MeJa ( $r=0.917)$ were superior to the control $(r=$ $0.607)$. Preventive and curative activities of post-harvest treatments have been reported in the literature, such as the use of sodium silicate resistance inducer for the control of Penicillium digitatum and Penicillium italicum, showing an effective result (MOSCOSO-RAMÍREZ; PALOU, 2013).

By correlating the phenolic compounds in pulp and peel, the ASM $(r=0.925)$ and IMI $(r=0.707)$ inducers were above the control $(r=0.562)$. In the association between antioxidant capacity and total phenols, both in peel, the selenium inducers $(r=0.883)$ and silicon $(r=$ $0.861)$ were higher than the control $(r=0.801)$. In the antioxidant capacity of the endocarp correlated to peel, only the MeJa inducer $(r=0.739)$ was higher than the control $(r=0.546)$. MeJa has been investigated in the role of plant defense in bean (Phaseolus vulgaris L.) and was responsible for influencing many metabolic functions, such as biogenesis, protein degradation and cellular defense (OLIVEIRA et al., 2015).

Table 1. Coloring ( $\mathrm{L}^{*}$ and $\left.\mathrm{a}^{*}\right)$, titratable acidity (\% citric acid), soluble solids ( $\left.{ }^{\circ} \mathrm{Brix}\right)$ and ascorbic acid (mg $\left.100 \mathrm{~g}^{-1}\right)$ of 'Ortanique' tangor fruits due to resistance inducers applied in pre-harvest and periods of refrigerated storage with subsequent simulation of commercialization time ( 7 days at $\left.20 \pm 1^{\circ} \mathrm{C}\right)$ in the 2015 and $2016 \mathrm{crops}$. UFPel, Pelotas/RS.

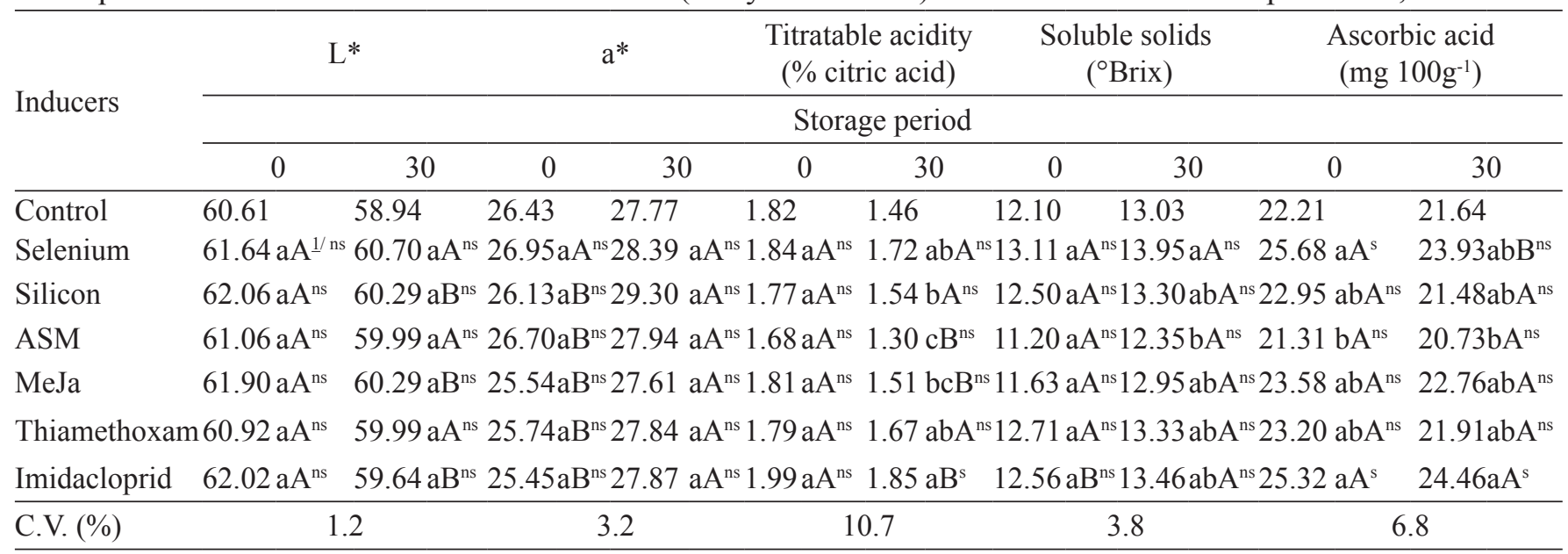

1/Means followed by the same lowercase letter in the column do not differ by the Tukey test $(\mathrm{p} \leq 0.05)$ comparing the inducers in each storage period. Means followed by same uppercase letter in the row do not differ by the $t$ test $(p \leq 0.05)$ comparing the storage of each inducer. Letters followed by ${ }^{\mathrm{s}}$ or ${ }^{\mathrm{ns}}$, significant and not significant, respectively, in relation to the control (no inducer) by the Dunnett test ( $\mathrm{p} \leq 0.05$ ). C.V.: coefficient of variation; ASM: Acibenzolar-s-methyl; MeJa: methyl jasmonate. 
Table 2. Total phenolics (mg CAE $100 \mathrm{~g}^{-1}$ ) and antioxidant capacity (DPPH, $\mu \mathrm{g}$ TEAC $\mathrm{g}^{-1}$ ) in pulp and peel of 'Ortanique' tangor fruits in resistance inducers function applied in pre-harvest and periods of refrigerated storage with posterior simulation of commercialization time ( 7 days at $20 \pm 1^{\circ} \mathrm{C}$ ) in the 2015 and 2016 crops. UFPel, Pelotas/ RS.

\begin{tabular}{|c|c|c|c|c|c|c|c|c|}
\hline \multirow{3}{*}{ Inducers } & \multicolumn{2}{|c|}{$\begin{array}{l}\text { Total phenolics } \\
\left.\text { (mg EAC } 100 \mathrm{~g}^{-1}\right) \\
\text { in pulp }\end{array}$} & \multicolumn{2}{|c|}{$\begin{array}{l}\text { Total phenolics } \\
\left(\mathrm{mg} \text { EAC } 100 \mathrm{~g}^{-1}\right) \\
\text { in peel }\end{array}$} & \multicolumn{2}{|c|}{$\begin{array}{c}\text { DPPH }\left(\mu \mathrm{g} \text { TEAC } \mathrm{g}^{-1}\right) \\
\text { in pulp }\end{array}$} & \multicolumn{2}{|c|}{$\begin{array}{c}\text { DPPH }\left(\mu \mathrm{g} \text { TEAC } \mathrm{g}^{-1}\right) \\
\quad \text { in peel }\end{array}$} \\
\hline & \multicolumn{8}{|c|}{ Storage period } \\
\hline & 0 & 30 & 0 & 30 & 0 & 30 & 0 & 30 \\
\hline Control & 75.89 & 60.76 & 451.69 & 428.57 & 85.66 & 76.46 & 629.35 & 530.19 \\
\hline Selenium & $85.10 \mathrm{abA}^{1 / \mathrm{ns}}$ & $73.44 \mathrm{aB}^{\mathrm{s}}$ & $457.68 \mathrm{aA}^{\mathrm{ns}}$ & $435.22 \mathrm{aA}^{\mathrm{ns}}$ & $109.75 \mathrm{aA}^{\mathrm{s}}$ & $97.10 \mathrm{aA}^{\mathrm{ns}}$ & $663.34 \mathrm{aA}^{\mathrm{ns}}$ & $545.18 \mathrm{aB}^{\mathrm{ns}}$ \\
\hline Silicon & 86.19abA ${ }^{\mathrm{ns}}$ & $75.53 \mathrm{aB}^{\mathrm{s}}$ & $500.04 \mathrm{aA}^{\mathrm{s}}$ & $477.59 \mathrm{aA}^{\mathrm{s}}$ & $123.19 \mathrm{aA}^{\mathrm{s}}$ & $109.82 \mathrm{aA}^{\mathrm{s}}$ & $721.95 \mathrm{aA}^{\mathrm{ns}}$ & $605.28 \mathrm{aB}^{\mathrm{ns}}$ \\
\hline ASM & $77.00 \mathrm{bA}^{\mathrm{ns}}$ & $66.18 \mathrm{aA}^{\mathrm{ns}}$ & $468.05 \mathrm{aA}^{\mathrm{ns}}$ & $445.10 \mathrm{aA}^{\mathrm{ns}}$ & $100.35 \mathrm{aA}^{\mathrm{ns}}$ & $92.01 \mathrm{aA}^{\mathrm{ns}}$ & $701.84 \mathrm{aA}^{\mathrm{ns}}$ & $583.18 \mathrm{aB}^{\mathrm{ns}}$ \\
\hline MeJa & $86.99 \mathrm{abA}^{\mathrm{ns}}$ & $76.16 \mathrm{aB}^{\mathrm{s}}$ & $485.07 \mathrm{aA}^{\mathrm{ns}}$ & $462.29 \mathrm{aA}^{\mathrm{ns}}$ & $116.39 \mathrm{aA}^{\mathrm{s}}$ & $102.01 \mathrm{aA}^{\mathrm{s}}$ & $763.20 \mathrm{aA}^{\mathrm{s}}$ & $644.54 \mathrm{aA}^{\mathrm{s}}$ \\
\hline Thiamethoxam & $82.82 \mathrm{abA}^{\mathrm{ns}}$ & $69.49 \mathrm{aB}^{\mathrm{ns}}$ & $479.18 \mathrm{aA}^{\mathrm{ns}}$ & $456.56 \mathrm{aA}^{\mathrm{ns}}$ & $111.44 \mathrm{aA}^{\mathrm{s}}$ & $93.15 \mathrm{aA}^{\mathrm{ns}}$ & $700.61 \mathrm{aA}^{\mathrm{ns}}$ & $581.78 \mathrm{aB}^{\mathrm{ns}}$ \\
\hline Imidacloprid & $90.92 \mathrm{aA}^{\mathrm{s}}$ & $76.08 \mathrm{aB}^{\mathrm{s}}$ & $507.04 \mathrm{aA}^{\mathrm{s}}$ & $484.42 \mathrm{aB}^{\mathrm{s}}$ & $124.87 \mathrm{aA}^{\mathrm{s}}$ & $111.57 \mathrm{aA}^{\mathrm{s}}$ & $734.03 \mathrm{aA}^{\mathrm{ns}}$ & $615.04 \mathrm{aB}^{\mathrm{ns}}$ \\
\hline C.V. $(\%)$ & \multicolumn{2}{|c|}{7.9} & \multicolumn{2}{|c|}{6.0} & \multicolumn{2}{|c|}{11.7} & \multicolumn{2}{|c|}{10.4} \\
\hline
\end{tabular}

${ }^{1 /}$ Means followed by the same lowercase letter in the column do not differ by the Tukey test $(\mathrm{p} \leq 0.05)$ comparing the inducers in every storage period. Means followed by same uppercase letter in the row do not differ by the $t$ test $(\mathrm{p} \leq 0.05)$ comparing the storage of each inducer. Letters followed by ${ }^{\mathrm{s}}$ or ${ }^{\mathrm{ns}}$, significant and not significant, respectively, in relation to the control (no inducer) by the Dunnett test ( $\mathrm{p} \leq 0.05)$. C.V.: coefficient of variation; ASM: Acibenzolar-s-methyl; MeJa: methyl jasmonate.

Table 3. Coloring ( $b^{*}$ and Hue), $\mathrm{pH}$ and SS/TA ratio of 'Ortanique'tangor fruits under effect of refrigerated storage with subsequent simulation of commercialization time ( 7 days at $20 \pm 1^{\circ} \mathrm{C}$ ) in the 2015 and 2016 crops. UFPel, Pelotas/RS.

\begin{tabular}{|c|c|c|c|}
\hline \multirow{2}{*}{ Variables } & \multicolumn{2}{|c|}{ Storage period } & \multirow{2}{*}{ C.V. $(\%)$} \\
\hline & 0 & 30 & \\
\hline $\mathrm{b}^{*}$ & $63.46 \mathrm{a}^{1 /}$ & $58.77 \mathrm{~b}$ & 1.8 \\
\hline Hue & $67.65 \mathrm{a}$ & $64.35 \mathrm{~b}$ & 1.6 \\
\hline $\mathrm{pH}$ & $3.16 \mathrm{~b}$ & $3.21 \mathrm{a}$ & 1.7 \\
\hline SS/TA ratio & $6.79 b$ & $8.41 \mathrm{a}$ & 12.0 \\
\hline
\end{tabular}

${ }^{1 /}$ Means followed by same lowercase letter in the row do not differ by the $t$ test $(p \leq 0.05)$ comparing the storage periods. C.V.: coefficient of variation.

Table 4. Fresh mass loss (\%) and rot index (\%) of fruits of 'Ortanique' treated in pre-harvest with resistance inducers in the 2015 and 2016 crops. UFPel, Pelota-/RS.

\begin{tabular}{|c|c|c|}
\hline Inducers & Fresh mass loss $(\%)$ & Rot index $(\%)$ \\
\hline Control & 13.83 & 5.00 \\
\hline Selenium & $7.74 b^{1 / s}$ & $0.83 \mathrm{a}^{\mathrm{s}}$ \\
\hline Silicon & $7.78 \mathrm{~b} s$ & $0.83 \mathrm{a}^{\mathrm{s}}$ \\
\hline Acibenzolar-S-methyl & $7.35 b^{\mathrm{s}}$ & $0.83 \mathrm{a}^{\mathrm{s}}$ \\
\hline Methyl Jasmonate & $11.35 \mathrm{a}^{\mathrm{ns}}$ & $0.83 \mathrm{a}^{\mathrm{s}}$ \\
\hline Thiamethoxam & $8.23 b^{\mathrm{s}}$ & $0.83 \mathrm{a}^{\mathrm{s}}$ \\
\hline Imidacloprid & $8.25 \mathrm{~b}^{\mathrm{s}}$ & $0.83 \mathrm{a}^{\mathrm{s}}$ \\
\hline C.V. $(\%)$ & 34.7 & 58.8 \\
\hline
\end{tabular}

${ }^{1 /}$ Means followed by same lowercase letter in the column do not differ by the $t$ test $(p \leq 0.05)$ comparing the inducers. Letters followed by ${ }^{\mathrm{s}}$ or ${ }^{\mathrm{ns}}$, significant and not significant, respectively, in relation to the control (no inducer) by the Dunnett test ( $\leq \leq 0.05)$. C.V.: coefficient of variation. 


\section{Conclusion}

The application of resistance inducers reduces the percentage of fresh mass loss and rot index in fruits after 30 days of refrigerated storage. The inducers keep the phenolic compounds and antioxidant capacity, in both pulp and peel, throughout the storage period. Si, $\mathrm{MeJa}$ and IMI provide increase of phytochemicals when compared to the control.

\section{References}

AGHDAM, M.S.; ASGHARI, M.; BABALAR, M.; SARCHESHMEH, M.A.A. Impact of salicylic acid in postharvest physiology of fruits and vegetables. In: SIDDIQUI, M.W. Eco-friendly technology for postharvest produce quality. Cambridge: Academic Press, 2016. p.244-260.

ALBRECHT, U.; BOWMAN, K.D. Transcriptional response of susceptible and tolerant citrus to infection with Candidatus Liberibacter asiaticus. Plant Science, Amsterdam, v. 185/186, p. 118-130, 2012.

ALBRECHT, U.; MCCOLLUM, G.; BOWMAN, K.D. Influence of rootstock variety on Huanglongbing disease development in field-grown sweet orange (Citrus sinensis L. Osbeck) trees. Scientia Horticulturae, New York, v. 138, p. 210-220, 2012.

A.O.A.C. (Association of Official Analytical Chemists). Official Methods of Analisis; Editted by Sidney Williams. 16 ed. Arlington, 1997. 1141P.

AZEVEDO, C.L.L.; SILVA, J.A.A.; CARVALHO, J.E.B. Segunda versão de normas técnicas específicas (NTE) da produção integrada de citros no Brasil. Cruz das Almas: Embrapa Mandioca e Fruticultura, 2010. 19p. (Documento, 192)

BOCK, C.H.; PARKER, P.E.; COOK, A.Z.; GRAHAM, J.H.; GOTTWALD, T.R. Infection and decontamination of citrus canker-inoculated leaf surfaces. Crop Protection, Guildford, v. 30, p. 259-264, 2011.

BRAND-WILLIAMS, W.; CUVELIER, M.E.; BERSET, C. Use of a free radical method to evaluate antioxidant activity. Lebensmittel Wissenschaft und Technologie - Food Science and Technology, London, v. 28, n. 1, p. 25-30, 1995.
CHITARRA, M. I. F.; CHITARRA, A. B. Pós-colheita de frutas e hortaliças: fisiologia e manuseio. Lavras: ESAL/FAEPE, 2005. 2ed. 783p

CONCEIÇÃO, C.S.; FELIX, K.C.S.; MARIANO, R.L.R.; MEDEIROS, E.V.; SOUZA, E.B. Combined effect of yeast and silicon on the control of bacterial fruit blotch in melon. Scientia Horticulturae, New York, v. 174, p. 164-170, 2014.

DENG, L.; ZHOU, Y.; ZENG, K. Pre-harvest spray of oligochitosan induced the resistance of harvested navel oranges to anthracnose during ambient temperature storage. Crop Protection, Guildford, v. 70, p. 70-76, 2015 .

FAN, J.; CHEN, C.; YU, Q.; BRLANSKY, R.; ZHENGGUO, L.; GMITTER, F.G. Comparative Itraq proteome and transcriptome analyses of sweet orange infected by Candidatus Liberibacter asiaticus. Physiologia Plantarum, Lund, v. 143, n. 3, p. 235-245, 2011.

FAO. Faostat: production crops. Rome, 2016. Disponível em: $\quad$ http://faostat.fao.org/site/567/DesktopDefault. aspx?PageID=567\#ancor $>$. Acesso em: 10 nov. 2016.

GONZATTO, M.P.; SCHWARZ, S.F.; OLIVEIRA, R.P.; BENDER, R.J.; SOUZA, P.V.D. 'URSBRS Hada': Tangoreiro de maturação tardia de duplo propósito. Revista Brasileira de Fruticultura, Jaboticabal, v.37, n.2, p.524-527, 2015.

GRAHAM, J.H.; MYERS, M.E. Integration of soil applied neocicotinoid insecticides and acibenzolar-Smethyl for systemic acquired resistance (SAR) control of citrus canker on young citrus trees. Crop Protection, Guildford, v. 54, p. 239-243, 2013.

GRAHAM, J.H.; MYERS, M.E. Soil Application of SAR inducers imidacloprid, thiamethoxam, and acibenzolarS-Methyl for citrus canker control in young grapefruit trees. Plant Disease, New York, v. 95, n. 6, p. 720-729, 2011.

HANDA, N.; BHARDWAJ, R.; KAUR, H.; POONAM, D.K.; RATTAN, A.; KAUR, S.; THUKRAL, A.K.; KAUR, S.; ARORA, S.; KAPOOR, N. Selenium: an antioxidative protectant in plants under stress. In: AHMAD, P. Plant metal interaction emerging remediation techniques. Srinagar: Department of Botany, 2016. v.1, p.179-207. 
IMTIAZ, M.; RIZWAN, M.S.; MUSHTAQ, M.A.; ASHRAF, M.; SHAHZAD, S.M.; YOUSAF, B.; SAEED, D.A.; RIZWAN, M.; AZHER, M.N.; MEHMOOD, S.; TU, S. Silicon occurrence, uptake, transport and mechanisms of heavy metals, minerals and salinity enhanced tolerance in plants with future prospects: a review. Journal of Environmental Management, Berkeley, v. 183, n. 3, p. 521-529, 2016.

INMET - Instituto Nacional de Meteorologia. BDMEP Banco de Dados Meteorológicos para Ensino e Pesquisa. Brasília, 2016. Disponível em: http://www.inmet.gov.br/ portal/index.php?r=bdmep/bdmep. Acesso em: $12 \mathrm{dez}$. 2016.

INSTITUTO ADOLFO LUTZ. Métodos físicoquímicos para análise de alimentos. 4. ed. São Paulo: Instituto Adolfo Lutz, 2008. v. 1, 1020 p.

JACOBS, M.B. The chemical analysis of foods and food products. New York: Van Nostrand, 1958. 979 p.

KOLLER, O.L. (org.) Citricultura catarinense. Florianópolis: EPAGRI, 2013. 319p.

KÖPPEN, W.; GEIGER, R. Klimate der Erde. Gotha: Verlag Justus Perthes. 1928. Wall-map $150 \mathrm{~cm} x 200 \mathrm{~cm}$.

LEME, J.J.; MALAVOLTA, E. Determinação fotométrica de ácido ascórbico. Anais da Escola Superior de Agricultura Luiz de Queiroz, Piracicaba, v. 7, p. 115$129,1950$.

MACHADO, F.L.C.; COSTA, J.M.C.; BATISTA, E.N. Application of carnauba-based wax maintains postharvest quality of 'Ortanique' tangor. Food Science and Technology, Melbourne, v. 32, n. 2, p. 261-266, 2012.

MINOLTA. Precise color communication: color control from feeling to instrumentation. Tokyo: Konica Minolta, 1994. 49p.

MOSCOSO-RAMÍREZ, P.A.; PALOU, L. Evaluation of postharvest treatments with chemical resistance inducers to control Green and blue molds on Orange fruit. Postharvest Biology and Technology, Amsterdam, v. 85 , p. 132-135, 2013.

MOULEHI, I.; BOURGOU, S.; OURGHEMMI, I.; TOUNSI, M.S. Variety and ripening impact on phenolic composition and antioxidant activity of mandarin (Citrus reticulate Blanco) and bitter orange (Citrus aurantium L.) seeds extracts. Industrial Crops and Products, Amsterdam, v. 39, p. 74-80, 2012.
NETO, A.C.R.; MARASCHIN, M.; DI PIERO, R.M. Antifungal activity of salicylic acid against Penicillium expansum and its possible mechanisms of action. International Journal of Food Microbiology, Turin, v. 215, p. 64-70, 2015.

OLIVEIRA, M.B.; JUNIOR, M.L.; GROSSI-DE-SÁ, M.F.; PETROFEZA, S. Exogenous application of methyl jasmonate induces a defense response and resistance against Sclerotinia sclerotiorum in dry bean plants. Journal of Plant Physiology, Amsterdam, v. 182, p. 13$22,2015$.

PACHECO, C.A.; SCHINOR, E.H.; AZEVEDO, F.A.; BASTIANEL, M.; CRISTOFANI-YALY, M. Characterization of fruits of Tangor TM x LP 290 for fresh fruit market. Revista Brasileira de Fruticultura, Jaboticabal, v.36, n.4, p.805-812, 2014.

PINTO, J.A.V.; THEWES, F.R.; SCHORR, M.R.W.; CECONI, D.L.; BRACKMANN, A.; HAMANN, J.J.; FRONZA, D. Mass loss induction on physical and chemical qualities of 'Murcott' Tangor during cold storage. Bioscience Journal, Uberlândia, v.31, n.5, p.1325-1332, 2015.

QUAGLIA, M.; EDERLI, L; PASQUALINI, S; ZAZZERINI, A. Biological control agentes and chemicas induceres of resistance for postharvest control of Penicillium expansumLink.on apple fruit. Postharvest Biology and Technology, Amsterdam, v. 59, n. 3, p. 307-315, 2011.

ROBERT-SEILANIANTZ, A.; GRANT, M.; JONES, J.D. Hormone crosstalk in plant disease and defense: more than just jasmonate-salicylate antagonism. Annual Reviews of Phytopathology, Palo Alto, v. 49, p. $317-$ 343, 2011.

SANTOS, H.G. Sistema brasileiro de classificação dos solos. 2.ed. Rio de Janeiro: Embrapa Solos, 2006. 306 p.

SIBOZA, X.I.; BERTLING, I.; ODINDO, A.O. Salicylic acid and methyl jasmonate improve chilling tolerance in cold-stored lemon fruit (Citrus limon). Journal of Plant Physiology, Amsterdam, v. 171, n. 18, p. 1722-1731, 2014.

SWAIN, T.; HILLS, W.E. The phenolic constituents of Punnus domestica. The quantitative analysis of phenolic constituents. Journal of the Science of Food and Agriculture, Washington, v. 19, p. 63-68, 1959. 
WANG, Y.; LIU J. Exogenous treatment with salicylic acid attenuates occurrence of citrus canker in susceptible navel Orange (Citrus sinensis Osbeck). Journal of Plant Physiology, Amsterdam, v. 169, n. 12, p. 1143-1149, 2012.

ZENG, R.; ZHANG, A.; CHEN, J.; FU, Y. Postharvest quality and physiological responses of clove bud extract dip on 'Newhall' navel orange. Scientia Horticulturae, New York, v. 138, p. 253-258, 2012.
ZHICHAO, W.; FUHUA, W.; SHUAI, L.; YINGQIONG, D.; FURONG, L.; RUIYING, D.; DIAN, W.; JIE, Z. Comparative responses to silicon and selenium in relation to cadmium uptake, compartmentation in roots, and xylem transport in flowering Chinese cabbage (Brassica campestris) L. ssp. Chinensis var. utilis) under cadmium stress. Environmental and Experimental Botany, Amsterdam, v. 131, p. 173-180, 2016.

ZHU, Z.; CHEN, Y.; SHI, G.; ZHANG, X. Selenium delays tomato fruit ripening by inhibiting ethylene biosynthesis and enhancing the antioxidant defense system. Food Chemistry, New York, v. 219, p. 179-184, 2017. 